\title{
Concepts and Dimensions of Human Dignity in the Christian Tradition
}

\author{
Sigrid Müller \\ Catholic Theological Faculty, Institute for Systematic Theology and Ethics, \\ University of Vienna, Vienna, Austria \\ sigrid.mueller@univie.ac.at
}

\begin{abstract}
This paper investigates the extent to which Christian tradition can be used to support human dignity and human rights in contemporary society. It explores the Christian tradition for ideas that correspond to the four main dimensions of human dignity: anthropological, moral, legal, and practical. It examines how these dimensions relate to the two main Christian perspectives that define human dignity, namely the imago Dei paradigm and dignity of the human soul or person. Concluding observations demonstrate that the corresponding Christian ideas offer a solid foundation for developing a strong Christian narrative and engagement in support of human dignity and human rights. However, an analysis of the two dominating concepts also indicates that a reception that excludes the universal aspect of the imago Dei paradigm can endanger a full acceptance of human dignity and human rights. Therefore, it is necessary to continue existing ecumenical efforts to create a complementary reading of the two traditions.
\end{abstract}

\section{Keywords}

human dignity - human person - God's image and likeness - Christianity

\section{Introduction}

Although scholars have demonstrated a lack of direct influence of Christian Churches on the formulation of the Universal Declaration of Human Rights, it is acknowledged that the Christian tradition forms part of the longer tradition on human dignity and human rights. In addition, faith traditions are gradually 
regarded as important for maintaining and supporting basic human insights and societal values that a secular state cannot produce itself. ${ }^{1}$ This general claim can also be applied to human dignity and human rights. Both need support at the level of acknowledgement, personal practice, argumentative support and legal codification, as well as supporting narratives. ${ }^{2}$ The Christian tradition provides a narrative and history that implicitly supports and justifies human dignity and human rights, even though these have been obscured, and even suppressed, at times throughout that tradition. This contribution sets out to review some aspects of the Christian tradition with regard to human dignity, human rights, and their interrelationship, and searches for aspects that can contribute to contemporary discussions on human dignity.

In this endeavour, we must be aware of the fact that human dignity and human rights in their modern understanding are not identical with what we can find in a tradition which reaches back in time for more than 2000 years. Konrad Hilpert remarks that we should not speak of identical elements in Christian tradition, but of "corresponding ideas and intentions". ${ }^{3}$ From the outset, I acknowledge that this overview is not comprehensive and can only highlight some aspects of the Christian tradition that demonstrate its contributions to these discussions. ${ }^{4}$

\section{Contemporary Dimensions of Human Dignity as a Hermeneutical Background}

In order to explore the Christian tradition and its relevance for societal, philosophical, and ethical discourse on human dignity, we begin by focusing more

1 The German constitutional judge Ernst-Wolfgang Böckenförde pointed at the importance that faith traditions have for fostering societal values, which the state itself cannot produce with its own means. Ernst-Wolfgang Böckenförde, Staat, Gesellschaft, Freiheit. 1976, p. 6o: "The liberal (German 'freiheitlich'), secularized state lives by prerequisites which it cannot guarantee itself." For more details cf. Große Kracht, Fünfzig Jahre Böckenförde-Theorem.

2 Joas, The Sacredness of the Person, p. 190-191.

3 Hilpert, Die Menschenrechte, p. 189 defines the relationship between human rights and ideas of the antiquity and the Jewish-Christian tradition as "relationship of correspondence", which allows a theological argument in favour of human rights, but recognizes that the formulation and declaration of human rights was not a direct consequence of theological reflections and actions of the Church.

4 I will several times refer to the more comprehensive studies of Barth, Gottebenbildlichkeit und Menschenwürde; Hilpert, Die Menschenrechte; Schockenhoff, Ethik des Lebens; Schaede, Würde; von der Pfordten, Menschenwürde, and the contributions published in The Cambridge Handbook of Human Dignity. 
on the contemporary context and concerns than historical context and concerns. What, then, are the main concerns in contemporary discussions on human dignity? In short, we can find four dominant dimensions of human dignity that are distinct but related. These dimensions are: first, human dignity as an anthropological principle signifying the intrinsic worth of human beings; second, human dignity as a moral principle, namely as the foundation of morality, moral rights, and duties; third, human dignity as a legal principle, namely as a formal or material basis for the legislation of human rights; and fourth, human dignity as a practical principle, namely as the object and aim of a practice-oriented virtue ethics or normative ethics (e.g., bioethics). Human dignity, then, encompasses the realms of anthropology, moral rights and obligations, human rights in their legal interpretation, and moral practice. Before exploring the historical context and concerns of the Christian tradition and its implications for understanding the four dimensions of human dignity, I first briefly explain those dimensions.

(1) Human dignity as a fundamental anthropological principle expresses the idea that human beings have an ontological quality with moral implications that is inseparable from the definition of the human being. It consists of a worth that is an intrinsic characteristic of every individual human person, which often is explained in relationship to the special position of human beings in comparison to non-human creatures.

(2) Human dignity as a moral principle in its relationship to moral rights and duties refers to human dignity as a moral quality that entitles humans to be treated by others with respect ( $2 \mathrm{a}$ - passive dimension), which finds its expression in negative moral rights, e.g. not to be deprived of one's life. On the other hand, there is a corresponding moral duty, namely, to act according to one's dignity, which means to respect other people's rights, e.g., their right to life ( $2 \mathrm{~b}-$ active dimension).

(3) Human dignity as a foundational principle of legal rights presupposes that human dignity is intrinsically linked to moral rights and that from these moral rights some fundamental negative legal rights can be deduced ${ }^{5}$, namely such aspects as the right to life, not to be tortured, or held in slavery, which are included in the Universal Declaration of Human Rights. ${ }^{6}$

5 E.g., after the Second World War, the term human dignity entered the Federal Council's Basic Law for the Federal Republic of Germany. In its art. 2, it guarantees the right to life, physical integrity, and freedom of the person. On the explicit or implicit presence of the concept of human dignity in other constitutional texts cf. Barak, Human Dignity.

6 The Virginia declaration of rights (1776) already guarantees the enjoyment of life and liberty, and the Declaration of Human Rights (1948) in art. 3 refers to a right to life, freedom and security. See Schockenhoff, Ethik des Lebens, p. 241. 
(4) Human dignity as a part of moral practice is based on the practical insight that realizing human dignity needs to be put into practice in everyday life. This dimension is a further specification of the active dimension ( $2 \mathrm{~b}$ ). That human beings can live in a dignified manner is dependent, in large part, on many personal and social factors and the way in which we construct social relationships. In this sense, promoting the dignity of others is an aim of personal practice; this practical aim concentrates on the potential effects on human dignity by shaping social structures and envisaging the impact of concrete actions, e.g., in the context of nursing homes.

All these dimensions ignite extensive philosophical and social debates and merit in depth study. ${ }^{7}$ In this paper, however, the four dimensions only serve as a hermeneutical point of departure to discover similar concerns in the history of Christianity.

The Universal Anthropological Principle of the Imago Dei Paradigm

Human dignity as an anthropological principle is usually identified with the biblical paradigm of imago Dei in current Christian ethical arguments, that is the biblical understanding of the human being as created in the image (Hebrew: selem) and likeness (Hebrew: demut) of God (Genesis 1:26-27). This statement is very important because it can only be found in three passages of one book in the Hebrew Bible which are situated closely together (Genesis 1:26-27; 5:1; 9:6). These passages do not, however, specifically state human dignity. Therefore, some interpretation regarding the semantics and the ancient context is needed to demonstrate their identification with this concept.

According to biblical scholars, these references have as interpretative background the process of coming to understand that human beings should not make any representations of God, any statues. Rather, the human being himself/herself is God's statue, i.e., God's representative on earth. The relationship between original and image expresses an immediate relationship between

7 The four dimensions of human dignity are closely related yet open huge fields of discussion in philosophy, ethical theory and theological ethics, which cannot be presented here. As an example, authors who define dignity only in the fourth sense, as e.g. Steven Pinker, criticise adopting the term for the basic rights of a person. Other authors, as e.g. Hans Joas, see human rights as an accomplishment of modernity, and human dignity as source, but not as cause for human rights. Cf. Pinker, The Stupidity of Dignity; Joas, The Sacredness of the Person. 
human beings and God - there are no intermediary beings between them. ${ }^{8}$ Instead, humans themselves are connected with both earth and heaven. ${ }^{9}$ They enable God's presence, they are a "living statue" (Hebrew: selem). ${ }^{10}$

This privileged place establishes the intrinsic difference from other creatures because nothing else can represent God, and it conveys an ontological hierarchy of terrestrial beings, because human beings come closest to God in the way they are created. ${ }^{11}$ The sacred stature of human beings is therefore strongly connected with their responsibility. Humans are told to participate in God's stewardship over creation and therefore have an active and responsible role (Gen 1:27). ${ }^{12}$ The textual addition and likeness, however, hints at the difference between God and human beings and shows that though being closely related to each other, God and human beings are not the same. ${ }^{13}$

With regard to the oriental context, the distinctive difference of the biblical text is that it confers the high position to all human beings, and not only to wise persons, e.g., kings. ${ }^{14}$ Rather, whoever has the image of a human being is a representative of God..$^{15}$ This universal understanding has been explained as a result of social "democratization" happening around 500 вС, during the exile of the people of Israel. The promise that God gave to David (2 Samuel 7:12-16) is re-interpreted as a promise to all people: because of God's universality, it

8 The relationship between God and man is emphasised to different degrees in the scholars' account. Some authors interpret the relationship between God and the imago Dei primarily as theological in the sense that human beings depend on God's supporting activity in order to be an image of God. Most others argue, on the contrary, that it is the relationship of human beings towards each other and creation, and not the personal relationship between God and human beings, which the texts point out. Cf. Schüle, Der Prolog der hebräischen Bibel, p. 97.

9 Genesis 1-11 übersetzt und ausgelegt, p. 150.

10 Genesis 1-11 übersetzt und ausgelegt, p. 149-152. The designation living statue is taken from Janowski, Die lebendige Statue Gottes.

11 McKeown, Genesis, p. 27: "Although it is difficult to ascertain the meaning of the 'image', it is closely associated with the uniqueness and distinctiveness of humans in the created order; the image of God sets humans apart from all creatures. The corollary of this is that God can have a closer relationship with humans than with the animals."

12 McKeown, Genesis, p. 27: "Yet, rather than implying empowerment to exercise dictatorial rule over the rest of creation, the verbs in this context of creation and blessing should be understood as indicating a supremacy that is harmonious and mutually beneficial."

13 Genesis 1-11 übersetzt und ausgelegt, p. 152. The addition of likeness to image avoids the false imagination that God looks like a human being; see Barr, The Image of God in the Book of Genesis, p. 24.

14 Schellenberg, Der Mensch, das Bild Gottes?, p. 386-387, p. 392 shows that the aspect of equality marks a difference with respect to other oriental contexts, while the relationship of man and God and of man and animals are common ground.

15 Schellenberg, Der Mensch, das Bild Gottes?, p. 141 et seq. 
extends beyond the chosen people of Israel and encompasses all humankind. ${ }^{16}$ The protection of the life of every person is the logical consequence of the imago Dei paradigm, which also excludes natural hierarchies among human beings. ${ }^{17}$ The text by itself makes a universal statement without any restrictions regarding origin, sex, or religious belief. ${ }^{18}$

Apart from that, it is important to note that the imago Dei paradigm refers to the whole human being, not to some specific properties as "the exterior appearance, the upright corporal position or the shape of the body or mental capacities as freedom of will and intellect". 19 The question of which feature of the human being warrants the designation imago Dei "misses the point" of the Hebrew text. ${ }^{20}$

Without using the term dignity, the biblical text already brings some of the elements of our contemporary understanding of human dignity to the fore. The text refers to its universal, anthropological, and ontological dimensions, which express that all human beings, all members of the species, do enjoy a privileged position in the hierarchy between God and the rest of creation, and equality amongst themselves (1). Secondly, from this privileged position a moral right and duty to mutual respect and protection of life is deduced (2a, b). Human beings should exercise their personal freedom and responsibility within their relationships (2). The text could also be interpreted as stipulating the creation of laws and possible applied-ethical aspects by evoking human beings' stewardship regarding non-human creation $(3,4)$. In the biblical understanding, all these elements are connected and cannot be separated from each other. The danger exists that we read too much of our contemporary understanding of human dignity into the passage of the imago Dei paradigm. Yet comparisons to the oriental context provide evidence that the text confirms the fundamental equality of all human beings and that all are endowed with responsibility. It is therefore consistent with the intention of the text, when it is used today to support the philosophical and political claims for the universality of human dignity and basic human rights.

One precautionary comment needs to be made regarding the uniqueness of the universal account of human dignity made in the text of Genesis. As has been noted, the universal aspect of the imago Dei paradigm characterizes the Hebrew text in its ancient regional context and has become an irrevocable

\footnotetext{
16 Barth, Gottebenbildlichkeit und Menschenwürde, p. 329.

17 Schüle, Der Prolog der hebräischen Bibel, p. 94 et seq.

18 For a restricted interpretation in the sense that this passage refers only to the chosen people see the reference offered by Jervell, Bild Gottes I, p. 492.

19 Jervell, Bild Gottes I, p. 492.

20 Schüle, Der Prolog der hebräischen Bibel, p. 96.
} 
ingredient of Christian anthropology. However, this important insight should not make us conclude that only the Hebrew Bible provided a universal anthropological idea of the prominent role of human beings in the context of creation. A comparative study of cultures and texts might bring similar meanings of creation accounts in other cultures and texts to the fore. ${ }^{21}$

\section{Human Beings as Image of Christ: the Distinct Fellowship Model in the New Testament Letters}

In the New Testament, a major shift occurs regarding the imago Dei paradigm, which originates in the intention to accommodate Christ in the relationship between human beings and God. There are seven passages where the word image (Greek: eikon) is used to designate the relationship between human beings and God. All of them are located in the letters of St. Paul and in the letter to the Colossians. For both authors, Christ is the true image of God (Greek: eikon tou theou; 2 Corinthians 4:4, Colossians 1:15) to whom Christians should orient themselves. They are Christ's image (Romans 8:29: image of the son of God) or they are transformed to God's image (Colossians 3:9-10) or to Christ's image through the Holy Spirit (2 Corinthians 3:18). Christians are created from dust as are all human beings, but through faith in Christ they are created as spiritual beings in his image (1 Corinthians 15:49). Through Christ human beings are created anew; their earthly lives are transformed and they become the image of God. St. Paul warns, however, that if they turn away from God, they can lose the quality of being God's image (Romans 1:23).

The New Testament passages show a dynamic and spiritual understanding of what it means to be an image of God; they refer to the transforming power of the Holy Spirit that creates a new quality in the human being, and reflect to a much lesser degree the aspect of "natural" creation. Apart from that, Paul uses the expression image of God to signify an eschatological quality that human beings will acquire through resurrection (1 Corinthians 15:49; Romans 8:29; 2 Corinthians 3:18). ${ }^{22}$ The question arises: how should this shift in the understanding of the imago Dei be evaluated? Looking at the context of the letters,

21 E.g., the Bantu African culture does speak about the dignity of human beings in a very similar way, uniting the aspects of equality, universality, and moral responsibility. See Tesha, Human Dignity as Basic Foundation.

22 This eschatological interpretation, as well as the passage in which he calls the woman a reflection of the man and the man an image of God (1 Corinthians 11:7) have been explained as "pedagogical use". In James 3:9 a similar pedagogical use can be observed. Cf. Jervell, Bild Gottes I, p. 494-498. St. Augustine explains that image belongs to the human 
we can observe that they are speaking to particular Christian communities. Therefore, the fellowship paradigm overlays the general anthropological and universal aspects in Paul's account of the imago Dei paradigm. However, it is theologically challenging to interpret Paul's manoeuvring between his emphasis on Jesus Christ being the universal redeemer and centre of fellowship, and his recognition of the inherent moral capacity of all human beings who are endowed with conscience and can fulfil God's law (Romans 2:14). It seems that, with respect to moral standards, Paul does not draw an absolute line of demarcation between the Christian communities and pagan multicultural societal backgrounds. ${ }^{23}$ This overlap of moral standards warrants Breitsameter's comment: "societal obligations are fulfilled by works, religious communication is marked by a discourse about grace." 24

We can conclude that Paul recognizes two types of universality. First, he shares with the imago Dei paradigm that universality is necessary because it is based on the monotheistic God who relates to all human beings. ${ }^{25}$ But, while in the imago Dei paradigm the consequence is equality by creation, and therefore by nature, Paul interprets nature as fallen and redeemed by Christ, and man's status before God as one that is affirmed by acting according to the law (the Tora) with the help of grace. Second, Paul refers to the moral capacity and obligation as universal. In his eschatological view, however, only God is able to judge who has acted righteously. Paul's reference to inborn moral knowledge does not serve to found a natural law theory, but rather to show that it is not enough to know the law; what counts is to knowingly or unknowingly fulfil it. ${ }^{26}$

We can summarize that already in New Testament times we detect the origins of a bifurcation of universal and particular approaches to the imago Dei paradigm. Though in both accounts, a monotheistic vision of God for all human beings forms the background, the first pathway, initiated by the imago Dei paradigm that relates to creation will be developed further along the path of natural reason and natural law theory, and can lead also to engaging in legal issues. The second way, related to the idea of redemption, emphasizes the recreation in the spirit of those who follow the gospel of Christ, and therefore offers a particular model of Christian fellowship. It will lead to reflections about the interior dimension of the human being seeking God, which more often relate to the term dignity. This is surprising because in today's understanding

being as such, and therefore to both man and woman together, but not if a certain function is regarded, as being the helpmate. Cf. Augustine, On the Trinity, p. 89 (XII, 7, 9-10). Cf. Breitsameter, Sünde und Schuld, p. 266.

24 Breitsameter, Sünde und Schuld, p. 267.

25 Breitsameter, Sünde und Schuld, p. 263.

26 Breitsameter, Sünde und Schuld, p. 263 et seq. 
of human dignity and human rights, we connect human dignity in the first place to equality and intrinsic worth, which are expressed more directly in the imago Dei paradigm, though it does not use the word dignity. However, when we look at recent philosophical discussions about how human dignity can be described more particularly, we find ideas that are very similar to the ones originating in Paul's fellowship and interiority paradigm, which will lead to the recognition of the individual human person.

These observations already make clear that the two ways do not always follow separate directions. Not only will the development of religious introspection in the Christian faith tradition pave the way for a universal philosophical understanding of the human subject and person, but also the natural law paradigm will change its emphasis from time to time, e.g., when some authors argue that its foundation is not reason alone, but God's law, and the two ways will intersect. Nevertheless, the differences between the two concepts, the natural law paradigm and the human person paradigm were perceived clearly because depending on different emphases on elements of Christian anthropology and biblical hermeneutics, the Christian denominations that developed along the history of Christianity also referred more strongly to one of the two ways. ${ }^{27}$ Experience of Human Dignity During the Roman Empire

In Early Christianity, several developments took place. Out of these developments emerged writings that reflect the particular Christian interpretation of human dignity, as we have seen it in Paul's letters, other writings witness a concept of human dignity based on religious introspection that focuses on some capacities of human beings, others again develop the existent universal concept of the imago Dei paradigm. ${ }^{28}$ In general, Christianity in the East developed more the introspection-oriented concept, while Christianity in the West developed more strongly the universal concept.

An important factor for the development of the insight into human dignity in Christianity was Christians' experience in the political and social context of the Roman Empire. During religious persecution, Christians felt that though

27 Barth, Gottebenbildlichkeit und Menschenwürde, p. 340. According to Barth, the emphasis on the dignity of the individual person dominated Christian tradition due to the influence of Augustine's theory of original sin, and was strong during the entire Old-Protestantism; it dominated the interpretation of the imago Dei paradigm in terms of natural law. 
they might lose their bodily life, they would save their soul and have eternal life when they remained faithful to their consciences and religious beliefs. They recognized that human dignity had an interior character, and contrasted it with the exterior, social honour, to which the Latin term dignitas referred. ${ }^{29}$ Against the background of such a socio-hierarchical understanding of dignity, Cyprian of Carthago (ca. 200-258) uses the term dignity to emphasize the inner worth of the martyrs which corresponds to their eternal glory. ${ }^{30}$ Similarly, the acts of the Christian martyrs refer to St. Paul's eschatological account of the imago Dei (2 Corinthians 3:18) where glory is promised to those who are faithful to Christ's command. ${ }^{31}$ In classical Latin the term dignity neither referred to an interior quality of a human being, nor was there a universal concept in the sense that dignity was a characteristic of all human beings. Only in one single remark, Cicero refers to the term dignity in the sense of a property of all human beings. ${ }^{32}$ The experience of Christians, therefore, inaugurated a change in the meaning of the term. Threat of martyrdom produced insight into the intrinsic worth of the persecuted, but this insight was addressed in the language of faith.

Similarly, in the life of the Christian communities, equal status and disregard for social differences were important values. The Christian communities were open to all social classes and thereby expressed their conviction of the equal

29 Cyprian's letters show a plurifold use of the Latin term dignity. A direct comparison between the Roman and the Christian understanding can be found in his letter no. 37 to Moyses and Maximus. Cf. Cyprian, The Letters, p. 52: "Now, therefore, let magistrates and consuls or proconsuls go by; let them glory in the ensigns of their yearly dignity, and in their twelve fasces. Behold, the heavenly dignity in you is sealed by the brightness of a years' honour, and already, in the continuance of its victorious glory, has passed over the rolling circle of the returning year."

30 Schaede, Würde, p. 28-30: Cyprian, The treatises, no. 3: On the Lapsed: "Let no one, beloved brethren, let no one decry the dignity of martyrs, let no one degrade their glories and their crowns."

31 The collection Acts of the Christian Martyrs, Hermbert Musurillo lists references to ${ }_{2}$ Corinthians 3:18, yet the text itself does not refer to the notion of imago Dei, but to the idea of eternal glory expressed in the verse.

32 Cicero, On duties (I, 106), p. 64: "And if we also wish to consider what is excellent and dignified in our nature, we should understand how disgraceful it is to waste away in luxury and to live effeminately and pampered, and how honorable it is to live frugally, contentedly, austerely, and soberly." Cf. the interpretation by von der Pfordten, Menschenwürde, p. 17-18. He emphases (p. 18-21) that no textual proof exists for assuming that Cicero took this idea from Stoicism, nor does the Roman Stoic philosopher Seneca refer to Cicero's understanding of dignity. Schelkshorn, Entgrenzungen, p. 256, shows that the ancient philosophers in spite of several universal ideas (e.g. Stoic cosmopolitanism) failed in drawing sufficiently political consequences, so that social inequality maintained its legitimacy. Cf. also Nussbaum, The cosmopolitan tradition, p. 64-96. 
dignity of human beings. ${ }^{33}$ As Rayner describes, "Instead of being a Stoic fragment of the Divine or a conglomeration of fortuitous atoms, man was raised to the dignity of son and joined heir with the 'Father of lights' [...]." ${ }^{34}$ Faith promoted equal treatment of all, however, without requiring legal guarantees (4).

When Christianity was finally tolerated by Galerius in 311, the Roman teacher of rhetoric, Lactantius (250-325), who had witnessed religious persecution, took the opportunity to embed Christian anthropology, the command to love one's neighbour (Mark 12:31), and the Decalogue into the framework of Roman natural law theory and Ciceronian philosophical eclecticism. In his introductory book to Christianity, the Divine Institutes, Lactantius offers an ethical approach based on the concept of a universal humaneness, which means a humanitarian attitude, to the emperor Constantine and the educated Romans. ${ }^{35}$ As a result of his ethics, Lactantius wrote against capital punishment and the killing of new-born children, arguing that human beings are made in the image of God and are, therefore, sacrosanct animals. ${ }^{36}$ While he knew that ethics depended on rational insight and moral instruction, he also referred to personal and religious freedom as logical pre-requisites that cannot be ruled by law: "True religion is an expression of one's inner convictions and devotion. And since those cannot be forced, true religion cannot be forced." ${ }^{37}$

Lactantius' melding Christian faith and Roman philosophy and law, therefore, strengthened two key elements of Christian anthropology: First, through a universal claim of the intrinsic worth of human beings based on creation and on natural law theory (1), in combination with the obligation to treat human beings according to their humanity and to respect their right to life $(2 \mathrm{a}, \mathrm{b})$. Second, by introducing a more transcendental-like understanding of personal freedom as a necessary condition for religious self-determination, understood in the deep sense of conscientious moral decision-making in the light of faith and morality (2).

In the Greek tradition, the interior aspects of human dignity stood at the centre. Influenced by Greek philosophy, Christianity shared the view that human beings were placed in an intermediate ontological position between God and material things. ${ }^{38}$ The soul, which has the capacity for grasping the

\footnotetext{
33 Rayner, Christian Society in the Roman Empire, p. 115.

34 Rayner, Christian Society in the Roman Empire, p. 116.

35 Cf. Wolfram Winger, Personalität durch Humanität, p. 532-547.

36 Lactantius, The Divine Institutes 6,10,1, p. 172; 6,20,17, p. 187. Cf. Winger, Personalität durch Humanität, p. 11.

37 Wolterstorff, Toleration, justice, and dignity, p. 380 et seq.

38 The Jewish philosopher Philo of Alexandria ( ${ }^{*} 24$ BCE-4O CE) had for the first time expressed the idea that human beings do have a mortal and an immortal nature, as far as
} 
eternal, stood at the centre of attention. Accordingly, Gregory of Nyssa (335394) explains that the human being lives at the frontier in so far as he or she has the freedom to develop himself/herself towards the material, or the immaterial. ${ }^{39}$ Therefore, Gregory compares the human soul to a king because it enjoys the capacity of self-governing. ${ }^{40}$ This capacity, which is expressed by virtue, immortality, righteousness, an inquiring mind, and understanding, relates human nature to divine nature as its image and enjoys the same dignity. ${ }^{41}$ In very similar terms, Gregory of Nazianz (329-390) describes that the need to decide one's direction in life has been a characteristic of human beings already in the moment of creation: "To be created is to have to make a choice."42

In both accounts of the Greek fathers of the Church, being an image of God is not described as natural in the sense of having intrinsic worth as a member

their body links them to the mortal, and their consciousness to the immortal. This perspective was adopted in Christianity already by St. Paul (1 Corinthians 15:49). Cf. Kobusch, Die Würde des Menschen - ein Erbe der christlichen Philosophie, p. 238.

39 Daniélou, Lêtre et le temps chez Grégoire de Nysse, p. 119. The dynamic of rational and irrational parts of the human being has been recently also emphasized by John Behr, The Rational Animal, p. 219-247. In the Latin tradition, e.g. Lactantius, in his De opificio Dei, makes clear that human beings are distinct from animals because they were not given exterior strength, but their soul as interior strength, endowed with perception and reason to defeat merely corporeal inclinations and to let themselves govern by the soul. Cf. Lactantius, On the Workmanship of God, c. 2, p. 282 et seq.

40 Cf. Kobusch, Die Würde des Menschen - ein Erbe der christlichen Philosophie, p. 246. He refers to Gregor Nyssenus, de vita Moysis II, p. 56, line 25-27: "And we are so to say the fathers of ourselves by producing ourselves as the ones that we want to be, and by manufacturing us through our will according to the model that we want." (transl. S.M.).

41 Gregory of Nyssa, On the making of man, c. 4-5: "[...] for the soul immediately shows its royal and exalted character [...], in that it owns no lord, and is self-governed, swayed autocratically by its own will [...] so the human nature also, as it was made to rule the rest, was, by its likeness to the King of all, made as it were a living image [...] but instead of the purple robe, clothed in virtue, which is in truth the most royal of all raiment, and in place of the sceptre, leaning on the bliss of immortality, and instead of the royal diadem, decked with the crown of righteousness; so that it is shown to be perfectly like to the beauty of its archetype in all that belongs to the dignity of royalty [...] purity, freedom from passion, blessedness, alienation from all evil, and all those attributes of the like kind which help to form in men the likeness of God: with such hues as these did the Maker of His own image mark our nature [...] you see in yourself word and understanding, an imitation of the very Mind and Word. Again, God is love, and the fount of love [...] the Fashioner of our nature has made this to be our feature too [...] thus, if this be absent, the whole stamp of the likeness is transformed. The Deity beholds and hears all things, and searches all things out: you too have the power of apprehension of things by means of sight and hearing, and the understanding that inquires into things and searches them out." Cf. Von der Pfordten, Menschenwürde, p. 22. 
of the species, but rather as natural in the sense of being endowed with a rational soul, which is more concretely characterised as the dynamic of free selfdetermination. A tension between the capacity to be an image of God and the moral challenge to live up to one's capacity $(2 \mathrm{~b})$ becomes evident. In contrast to the imago Dei paradigm, the moral dimension is not focussed primarily on other beings, but rather on the self-education of the soul. Based on Greek philosophy, Greek authors posed the question of what exactly can be described as divine in human beings. This leads to interiorizing the concept of the imago Dei paradigm.

In the West, the most important source for later mediaeval discussions about how the human soul resembles God is St. Augustine's (354-430) explanation that God's image and likeness are reflected in memory, intellect and will (or love) ${ }^{43}$ of the human soul. Regarding the inter-relationship of being, understanding and will (esse, nosse, velle) human beings are similar to the Holy Trinity. The image of God is present in all human beings as capacity to capture God and can only be obscured, but not removed. ${ }^{44}$ While plants and animals have a likeness (similitudo) to God which is "transmitted through reproduction", human beings receive the divine image (imago) "by the direct, spiritual act of God. The spiritual nature of this act lies in the twofold fact that the image is of God (Spirit), and the image is found in the mind, not the body."45

In this way, Augustine introduces a difference between the bodily nature (organized via the "rationes seminales") and the spiritual nature of man. As Drewer explains, "The soul exists in a type of reflective immediacy in which its primordial identity is given to it from that which the soul is not (i.e., God). This leads to the paradoxical conclusion that the soul is most itself when it is least its own." ${ }^{46}$ However, Augustine does not link these considerations to the term

43 Augustine, On the Trinity (XII, 7, 12; rational mind), p. 91; (XIV, 12; to remember, understand, love), p. 153 et seq.

44 Augustine, On the Trinity, (XIV, 4, 6), p. 142: “[...] whether this image be so effaced as almost to amount to nothing, or whether it be obscured and disfigured, or whether it be clear and beautiful - it always exists [...] and although it could be corrupted because it is not the hightest, yet because it is capable of the hightest nature and can be sharer in it, it is a great nature." Cf. Von der Pfordten, Menschenwürde, p. 23.

45 Drewer, Image, Identity, and Embodiment, p. 123, fn 26: "Augustine's version of Gen. 1:26 does not specify which dimension(s) of the human being is the image of God. But citing Paul (Eph. 4:23-24; Col. 3:10), Augustine is clear that the image of God is found in the soul or illuminated mind (Gn. Litt. 3.20.30) [...]."

46 Drewer, Image, Identity, and Embodiment, p. 127; p. 123: This understanding is based on the idea that the soul is not "governed by a potential-actual dynamic and oriented toward a universal structure (genus) that stands outside it [...]. The situation is different for the soul. The immediate and intimate relation between God and the soul generated by its 
of human dignity. ${ }^{47}$ Not human nature as such, not even the rational nature of the human soul, but the capacity to host the divine spirit makes human beings true images of God. In Augustine's account, the imago Dei paradigm receives a transcendental foundation.

However, we cannot conclude that the development of interiorizing the imago Dei paradigm dominated theology once it developed. The natural law approach and theological arguments are used closely together, e.g., when Ambrose of Milan (339-397) develops the idea of a society in which everybody cooperates and has the same dignity ${ }^{48}$ and argues with reference to the life of Christ that dignity does not depend on exterior honour but is present in situations of poverty and persecution. ${ }^{49}$ Leo the Great (ca. 400-461) resumes the theological explanation used by Paul that human beings were created in the dignity of their nature, which was destroyed by Adam, but rebuilt by Christ. ${ }^{50}$ Towards the end of the patristic period, Gregory the Great (540-604) uses the theological argument of incarnation to support an observation that he makes about natural law. By nature, he says, all human beings are born free, and only by the law of nations, they can be made slaves. From the perspective of the incarnation of Christ, slaves should be set free because the purpose of Christ's incarnation was to liberate human beings from servitude. ${ }^{51}$ Gregory's comment shows how Christian faith is used to defend a universal equality of human beings with societal consequences, even if Gregory does not go as far as postulating a change of the law of nations. Christological arguments are used in support of universalist philosophical ideas of human beings. At the same

origin is complemented by a similar situation in its identity. As part of intellectual creation, the soul exists, primordially speaking, in an intellectual act oriented toward God. The intimate relation generated here enables the identity of the soul as the image of God."

47 Schaede, Würde, p. 13.

48 Ambrosius, Exaemeron, dies 5, 15, 52, p. 178 et seq.: Sic a principio acceptam a natura exemplo avium politiam homines exercere coeperant, ut communis esset labor, communis dignitas [...] nemo audebat alium servitio premere, cuius sibi succcessuri in honorem mutua forent subeunda fastidia, nemini labor gravis, quem secutura dignitas relevaret.

49 Schaede, Würde, p. 28 et seq.

50 Leo the Great, Sermons 27, 6 p. 114: "Wake up then, o friend, and acknowledge the dignity of your nature. Recall that you have been made 'according to the image of God'. This nature, although it had been corrupted in Adam, has nevertheless been re-fashioned in Christ." Cf. Schaede, Würde, p. 31.

51 Hilpert, Die Menschenrechte, 97. Gregorius Magnus, Epistulae vi, 12, p. 803-805: Cum Redemptor noster (Grat. 12 q. 2 c. 68), totius conditor creaturae, ad hoc propitiatus humanam voluerit carnem assumere, ut divinitatis suae gratia dirupto quo tenebamur capti vinculo servitutis, pristinae nos restitueret libertati, salubriter agitur si homines quos ab initio natura liberos protulit, et jus gentium jugo substituit servitutis, (a) in ea qua nati fuerant (b) manumittentits beneficio libertate reddantur. 
time, or not much later, an offertory prayer of the Christian liturgy, which was used until the Second Vatican Council, refers to the human substance, and not to nature, which is founded in dignity by creation and re-founded again in Christ. ${ }^{52}$ The concepts of imago Dei paradigm, human dignity, and the human person are complementary, not contradictory, concepts.

\section{Mediaeval Accounts: the Individual Person and the Human Soul as Image of God}

The philosophers and theologians of the Middle Ages make different philosophical and theological ancient traditions available for modern times. As early as in the writings of the circle of Alcuin of York (735-804), the condition of man and the imago Dei paradigm are explained with reference to the dignity of human beings and they integrate many of the dimensions that had been developed in the first centuries. ${ }^{53}$ Human dignity is illustrated by the similarity between the activities of the human soul and the Holy Trinity, but also as the

52 Von der Pfordten, Menschenwürde, p. 23 regards this a first step in a development towards a modern philosophical understanding of a substantial human dignity. With respect to the text itself, he refers to the second edition of 1966 and quotes a text version which in the third edition is offered in the footnote as alternative reading: Deus qui humanae substantiae dignitatem mirabiliter condidisti et mirabilius reformasti. The text actually proposed by the edition reads slightly different, namely: Deus, qui in humanae substantiae dignitate + et mirabiliter condedisti <sic! > et mirabilius reformasti: da, quaesumus, nobis Iesu Christi filii tui: eius: divinitatis esse consortes, qui humanitatis nostrae fieri dignatus est particeps: per. Where the sign for an unreadable word $(+)$ is set, I would expect the Latin word "nos", meaning "us", so the text would read: "God, you who has founded us in the dignity of our human substance and has even more wonderfully restored us in it: Give us, so we pray, that we become fellows in the divinity of Jesus Christ, your son, who has deigned to participate in our humanity" [Trans. S.M.]. The difference of the texts is that in the main reading, dignity is consubstantial with and therefore an immediate expression of the human being and nothing that needs to be created apart from the human being: God did not create dignity, but the human being. Cf. Sacramentarium Veronense, p. 157, no. 1239. This text does not allude to the fall of man, though using the same word as does Leo in his letter for the refashioning in Christ (reformare) (see footnote 50). Though the meaning seems to be the same, the Sacramentarium uses the word substance and not nature. This could indicate that Boethius's definition of the human person as substance exerted some influence. For a comparation with the Latin text of Leo, cf. Leo Magnus, Sermones 27, 6, p. 220: Expergiscere, o homo, et dignitatem tuae cognosce naturae. Recordare te factum ad imaginem Dei (Genesis. 1, 26); quae, etsi in Adam corrupta, in Christo tamen est reformata.

53 Marenbon, From the Circle of Alcuin to the School of Auxerre, p. 16o, p. 158, which refer to the Dicta Albini, edited by Marenbon as part of his Appendix 1. 
particular capacity of human beings to gain knowledge of God and to love God. For Alcuin, God and man are related to such an extent that whoever does not love other human beings does not love God, and whoever knows the human being cannot not know God. ${ }^{54}$ The emphasis on the soul as image of God, therefore, brings the transcendent dimensions of the human soul to the fore.

Mediaeval texts also reflect on which capacities mirror God. In this sense, Hugh of Saint Victor (c. 1096-1141) already mentions the main two dimensions: he sees reason as image and love as likeness of God. ${ }^{55}$ Reason, in its various medieval accounts, can refer to intellectual virtue and the capability of self-reflection, to the mystical path towards a reunion with God, to practical reasoning and moral responsibility. ${ }^{56}$ For Thomas Aquinas, human dignity expresses the very purpose of human life, namely, a life according to reason. ${ }^{57}$ He mirrors the moral obligation to live up to one's inherent human dignity in a negative way when he argues that human beings can lose their dignity if they do not act according to their reason and freedom. ${ }^{58}$ Thus, the loss of dignity means the failure of not living up to it. ${ }^{59}$

Also ternary schemes are used to include theoretical and practical reason and will or love. In the case of Bonaventure (1221-74), the capacities of the human soul reflect God in the threefold structure of remembering, cognizing, and loving. ${ }^{60}$ He extends the imago dei paradigm to combine three different layers of human dignity that had been explained in the past. He calls the ontological, universal dignity of the human soul, which originates in creation, God's

54 Marenbon, From the Circle of Alcuin to the School of Auxerre, p. 164 (Text of Alcuin): Sicut enim qui non amat imaginem Dei, Deum non amare conuincitur, sic, qui non agnoscit imaginem Dei, Deum utique non agnoscere probatur.

55 Imbach, Human Dignity in the Middle Ages, p. 65. Hugo de Sancto Victore, De Sacramentis Christianae fidei, I, 6, 2.

$5^{6}$ Imbach, Human Dignity in the Middle Ages, p. 65-69.

57 Imbach, Human Dignity in the Middle Ages, p. 65; Thomas von Aquin, De veritate q. 25 a. 6 ad 2: Recessus autem a ratione, in qua tota dignitas humana consistit, ad turpitudinem pertinent.

$5^{8}$ Thomas Aquinas, Summa theologiae. Secunda secundae, 1-91, q. 64 a. 2 ad 3, p. 598: "By sinning man departs from the orderdine rationis recedit, and consequently falls away from the dignity of his manhood, insofar as he is naturally free, and exists himself, and he falls into the slavish state of the beasts, by being disposed of according as he is useful to others. [...] Hence, although it be evil in itself to kill a man so long as he preserve his dignity, yet it may be good to kill a man who has sinned, even as it is to kill a beast. For a bad man is worse than a beast, and is more harmful, as the Philosopher states (Polit. i, 1 and Ethic. vii, 6)."

59 Imbach, Human dignity in the middle ages, p. 71.

6o Bonaventura, Itinerarum mentis in deum (III,1), p. 303 b: nec se posset amare, nisi se nosset; nec se nosset, nisi sui meminisset. 
trace (vestigium); the dynamic soul that recognizes and loves God and participates in Him is the image of God (imago Dei); and, if human beings cooperate with God's grace, they can even reach similarity (similitudo) with God. ${ }^{61}$

Apart from reason and will, freedom is also seen as an expression of the imago Dei paradigm. For Bernard of Clairvaux (1090-1153), human dignity consists in the freedom of human beings, which makes them superior to other creatures and capable of ruling over them. ${ }^{62}$ Also late mediaeval thinkers, such as William of Ockham, argue for universal respect of each other not by referring to nature, but to the freedom of each other's will; "both acting morally and political authority presuppose the recognition of the freedom of others". ${ }^{63}$

Parallel to the imago Dei paradigm is the theory of the human person developed in light of the definition given by Boethius, namely, a person is an "individual substance of rational nature," which was applied to God, angels, and humans. ${ }^{64}$ This definition emphasized individuality, which was further explained as "incommunicable existence", as "existing for oneself", which has been said to provoke the ontological perspective of a "who" instead of a "what". ${ }^{5}$ In this sense, Alexander of Hales (1185-1245) "connects the notion of dignity with the concept of persons" ${ }^{66}$ Persons are said to be of highest dignity because they are moral beings (Alexander of Hales), because of their natural and moral dignity (Albertus Magnus), or because of their "self-governance (dominium sui), that is, independence in acting [...], thinking and willing",

61 Bonaventura, Sermones selecti de rebus theologicis 4,16, p. 571b: Ad cuius intelligentiam notandum, quod in creaturis reperitur triplex modus conformitatis ad Deum. Quaedam enim conformantur Deo sicut vestigium, quaedam sicut imago, quaedam sicut similitudo. Vestigium autem dicit comparationem ad Deum sicut ad principium causativum; imago autem non solum sicut ad principium, sed etiam sicut ad obiectum motivum; "eo enim est anima imago Dei, ut dicit Augustinus decimo quarto de Trinitate, quod capax eius est et particeps esse potest", scilicet per cognitionem et amorem. Similitudo autem respicit Deum non tantum per modum principii et obiecti, verum etiam per modum doni infusi. In contrast to the biblical text, Bonaventure uses similarity to signify a stronger unity of human being and God, not their difference.

62 Imbach, Human Dignity in the Middle Ages, p. 65; Bernard of Clairvaux, Concerning Grace and Free Will 9, 28, p. 25 et seq.

63 Imbach, Human Dignity in the Middle Ages, p. 69. For a development of the idea of the common good in the Middle Ages cf. Sigrid Müller, Gemeinwohldenken im Mittelalter.

64 Imbach, Human Dignity in the Middle Ages, p. 67; Boethius, Contra Eutychen et Nestorium/ Against Eutyches and Nestorius (c. III), p. 85: "[...] we have found the definition of person: "The individual substance of a rational nature."

65 Imbach, Human Dignity in the Middle Ages, p. 68; Ebneter, Exsistere: zur Persondefinition in der Trinitätslehre des Richard von St. Viktor (†n173), p. 68-69.

66 Imbach, Human Dignity in the Middle Ages, p. 68. 
which makes human persons the "most perfect being in the whole of nature".67 Aquinas and, at the beginning of the Renaissance, Petrarca rank human beings higher than angels because they are able to shape the world. ${ }^{68}$

To these approaches to the nature of human beings as persons, Aquinas adds reflections on the consequences for social living. Natural inclinations direct human beings' striving for knowledge, but also for community. In this respect, he integrates the Aristotelian concept of the human being as a social and political being into medieval political theory. As Imbach summarizes, human beings are social beings to a degree that "every human is every other's friend [...] 'by a certain general love"." ${ }^{69}$ However, upholding the idea of universal friendship does not prevent Aquinas from showing also some shortcomings with regard to the legal consequences of a universal understanding of morality and freedom. These limitations include the idea that the death penalty is justifiable with respect to the common good of society, or the belief that slavery can be deduced from natural law, which was partially based on the reception of Aristotle's idea of "natural inequality amongst human beings".70

In the field of socio-political consequences of universal human dignity, arguments against making a political distinction between human beings who have full dignity or are full citizens, and those who are not, arose in the Late Middle Ages from diverse directions, namely from the area of mysticism and from natural law theory. Both areas are based on high regard for the rational capacity of human beings. Acting according to reason is evaluated as acting according to divine nature. ${ }^{71}$ Political and legal consequences are discussed in the context of the Council of Constance. Paulus Wladimiri (1370-1434/36) interpreted the imago Dei paradigm as dignity by creation, which applies to all human beings. Since human beings are not entirely deprived from their dignity by original sin, the question whether the enemy is a Christian or not does

67 Imbach, Human Dignity in the Middle Ages, p. 68; Aquinas, Summa theologiae I, q. 29, a. 3 co.: Respondeo dicendum quod persona significat id quod est perfectissimum in tota natura, scilicet subsistens in rationali natura.

68 Schaede, Würde, p. 42; Steenbakkers, Human Dignity in Renaissance humanism, p. 88.

69 Imbach, Human Dignity in the Middle Ages, p. 70; Aquinas, Summa theologiae: Secunda secundae, q. 114 a. 1 ad. 2, p. 178: "Every man is naturally every man's friend by a certain general love [...]."

70 Imbach, Human Dignity in the Middle Ages, p. 71; Thomas Aquinas, Summa theologiae. Secunda secundae, q. 64, a. 2 resp.; a. 3 resp., p. 597-599; q. 57, a. 3 ad 2, p. 527.

71 Mieth, Human dignity in late-medieval spiritual and political conflicts, p. 76. He quotes Meister Eckhart, Expositio sancti Evangelii secundum Iohannem (no. 51:42): "For 'In the beginning was the word' also means: in the beginning was reason [...]. What is done in accordance with reason [...] emanates from God's countenance." 
not make a difference when it comes to the right to wage a war or not. ${ }^{72}$ In his arguments, Wladimiri not only defends intrinsic dignity (1), but also holds that the right to life follows from personal human dignity (2a), and at the level of ius gentium, also equal rights of non-Christian states can be deduced (3). Equality of human persons (1) and freedom of religion (2) are regarded as fundamental principles determining the formulation of law. Human Dignity Dominates

The Renaissance philosophers drew from ancient and mediaeval arguments while emphasizing human achievements. ${ }^{73}$ Since they have a positive perspective on human beings' capacities, they use the imago Dei and the incarnation paradigm for interpreting human beings. The fact that God became man shows the excellence of human beings, which exists especially in their way of understanding and acting. ${ }^{74}$ However, towards the end of the fifteenth century, new as well as inherited problematic sides on the interpretation of human dignity become apparent. On the one hand, the late Renaissance philosopher Pico della Mirandola, by describing the self-creating power of human beings, depicts them as dynamic beings that push the boundaries of species. Because they possess "an unlimited capacity for growth and development"75, they can become divine if they use their intellectual powers, but they can also degrade to animals or to a vegetative level. ${ }^{76}$ In this way, differences in equality between persons can be justified. ${ }^{77}$

Also, the ancient idea of natural slavery was taken up in a discussion in Valladolid (1550-1555) about the rights of the indios. Even Bartolomé de las Casas (1484-1566), the strong voice against the classification of the indigenous people as natural slaves, applies a development model when he argues that the "indios" possess the capacity of reason, which makes them apt for religious education, yet makes the acquisition of full human dignity dependent

\footnotetext{
72 Mieth, Human dignity in late-medieval spiritual and political conflicts, p. 81 et seq.

73 Stenbakkers, Human Dignity in Renaissance humanism, p. 92.

74 Stenbakkers, Human Dignity in Renaissance humanism, p. 88; Petrarch, De viris illustribus; Manetti, De dignitate et excellentia hominis.

75 Stenbakkers, Human Dignity in Renaissance humanism, p. 91.

76 Pico della Mirandola, On the dignity of man, p. 4-6. Cf. Stenbakkers, Human Dignity in Renaissance humanism, p. 91. Cf. Schelkshorn, Entgrenzungen, p. 163-204.

77 Cf. Stenbakkers, Human Dignity in Renaissance humanism, p. 99.
} 
on conversion to the Christian faith. ${ }^{78}$ The development model applied by Pico della Mirandola obviously was still influential.

On the other hand, a different approach developed, which had mediaeval natural law theory as its source. The founder of the school of Salamanca, Francisco de la Vitoria (1483-1546), made a significant step forward towards a universalism with political consequences. He argues that the Aristotelian idea of natural slavery opposes the Christian idea that all human beings are created in the image of God. Vitoria also declares that all rights deducible from nature have validity for all human beings, without regard to their faith. ${ }^{79}$ By referring to nature in the sense of species, and not to a development model of reason or will, he can develop a universal idea of human beings in the line of the imago Dei paradigm (1), and deduce legal rights that apply to everybody (3). As Hans Schelkshorn has shown, it needed the geographical and political extension of the European perspectives, especially with the discovery of the Americas, to promote a step-wise expansion of who counted politically and legally as a human being with dignity. ${ }^{80}$

\section{The "Non-Religious" Use of the Concept of Human Dignity in Modernity}

In the transition to Modernity, several elements contributed to a separation between the fields of theology, law, and philosophy. Natural law theory gained a non-religious outlook. Grotius and others argued "as if there was no God", which meant at that time that religious ideas were accepted but not used in the public sphere. ${ }^{81}$ The experience of the European confessional wars contributed to a focus on the weak sides of human beings. ${ }^{82}$ Reformation theology lead to a division between the public sphere, in which reasoning and acting righteously were important, and the personal and private relationship to God, where dignity was interpreted as God's free gift. ${ }^{83}$ In this way, aspects of human dignity related to the imago Dei paradigm and natural law seemingly gained a history, which was independent of Christian religion.

\footnotetext{
78 Pharo, The Council of Valladolid, p. 98.

79 Schelkshorn, Entgrenzungen, p. 275, p. 279.

8o Schelkshorn, Entgrenzungen, p. 208-231.

81 Hilpert, Die Menschenrechte, p. 103 et seq.

82 Westerman, Natural rights versus human dignity, p. 114.

83 Bayer, Martin Luther's conception of human dignity, p. 102-104; Bilaterale Arbeitsgruppe, Gott und die Würde des Menschen, p. 111-112.
} 
These developments can explain why human dignity is not present in classical human rights declarations of the 18th century, nor is it present in many important treatises based on natural law. Only Samuel Pufendorf refers to the term. As Westerman has argued, Pufendorf begins with the weakness in the nature of human beings who can only reach their true nature with guidance from a law that is deduced from a "higher insight". ${ }^{4}$ Human dignity therefore is not intrinsic to human beings in the sense of being given by nature, but needs to be "reached" by dominating and overcoming fallible nature. Pufendorf uses the dynamic model of human dignity to explain why there is a difference between the (bad) reality of social inequality and the (good) idea of the human being that should guide one's practice. ${ }^{85} \mathrm{He}$ portrays human dignity in its classical traits: equality of human beings, difference to animals because of the rational soul that has the capacity to understand and to make decisions $(1,2)$, duty to respect oneself, as well as the right to be respected by others $(2 a) .{ }^{86}$ Pufendorf's account of human dignity became very influential internationally because the abbreviated text version of his eight volume work, De jure naturae et gentium, was used as a text book in the Anglo-Saxon countries. ${ }^{87}$

The idea of an intrinsic human dignity, however, was formulated in the field of philosophy. In his third formula of the Categorical imperative, Immanuel Kant (1724-1804) describes moral autonomy and relates it to the idea of human dignity, which he defines as "inner worth". ${ }^{88}$ In this way, Kant creates a philo-

84 Westerman, Natural rights versus human dignity, p. 114 et seq.

85 Von der Pfordten, Menschenwürde, p. 30.

86 Hilpert, Die Menschenrechte, p. 105 et seq. On the complex relationship of Pufendorf's to Kant's account of human dignity cf. Saastamoinen, Pufendorf on Natural Equality, Human Dignity, and Self-Esteem, p. 39-62.

87 Saastamoinen, Pufendorf on Natural Equality, Human Dignity, and Self-Esteem, p. 39; Hilpert, Die Menschenrechte, p. 105. Samuel von Pufendorf wrote a short version of his eight volumes De jure naturae et gentium which has the title De officio hominis et civis juxta legem naturalem (1672).

88 Von der Pfordten, Menschenwürde, p. 29, p. 34. Kant compares things that have a value (prize) with human beings who have dignity, in his second part of the Metaphysics of Morals of 1789. Cf. Kant, Groundwork of the Metaphysics of Morals, p. 46: "[...] but what constitutes the condition under which alone something can be an end in itself does not merely have a relative worth, i.e. a price, but an inner worth, i.e. dignity." Also: Immanuel Kant, The Metaphysics of Morals, p. 225: "Every human being has a legitimate claim to respect from his fellow human beings and is in turn bound to respect every other. Humanity itself is a dignity; for a human being cannot be used merely as a means by any human being (either by others or even by himself) but must always be used at the same time as an end. It is just in this that his dignity (personality) consists, by which he raises himself above all other beings in the world that are not human beings and yet can be used, and so over all things. But just as he cannot give himself away for any price (this would conflict with his duty of self-esteem), so neither can he act contrary to the equally necessary 
sophical interpretation of human dignity that unites the intrinsic meaning of human dignity with its active and passive dimensions. ${ }^{89}$ Human dignity consists exactly in the capability of binding one's free will to objective moral principles. Both aspects - moral rights and moral duties - are connected to a universal vision in Kant's idea that the categorical imperative requires respect for every single person as an expression of humankind. ${ }^{90}$

However, Kant's philosophical account of the term did not meet immediately with a positive and wide reception. Especially in the Catholic realm, Kant initially was openly rejected because of his intent to develop an ethics without grounding it in a reference to God. ${ }^{11}$ During Kant's time, the term human dignity was used in public to denounce the social and economic states of affairs of the proletarian class as non-humane living conditions. ${ }^{92}$ In addition, the socio-political application of Kant's idea of a universal human dignity was also severely hampered by his theory of race. ${ }^{93}$

These developments show that human dignity as moral category and the possibility of deducing human rights are discussed in public predominantly outside the theological field in political, legal, and philosophical contexts. ${ }^{94}$ Due to different reasons, which also relate to the conflictual relationships of State and Church during these centuries, at least on the European continent, the Christian Churches did not take pioneering roles in modernizing the National States and pushing them to develop human rights. Rather, the

self-esteem of others, as human beings, that is, he is under obligation to acknowledge, in a practical way, the dignity of humanity in every other human being. Hence there rests on him a duty regarding the respect that must be shown to every other human being".

89 Von der Pfordten, Menschenwürde, p. 36, shows that the Anglo-Saxon countries and countries with a majority of Catholicism as Italy remained with a religious or theonomy-like understanding of human dignity, and also German philosophers as Hegel have situated human dignity in the religious background.

9o For a comprehensive account of the foundation of and duty related to human dignity, cf. Wagner, Die Würde des Menschen. Recently, Aleida Assmann has recalled the connection between rights and duties, cf. Assmann, Menschenrechte und Menschenpflichten.

91 For an example of the Catholic reaction, cf. Wasmaier-Sailer, Das Verhältnis von Moral und Religion.

92 Von der Pfordten, Menschenwürde, p. 39, refers to Ferdinand Lassalle's political activities.

93 Cf., e.g., Sandford, Kant, race, and natural history, p. 950-977. Kant's approach also needs to be corrected in the sense that human dignity "can be destroyed but not forfeited": cf. Kateb, Human dignity, p. 176.

94 For an evaluation of this period, a more detailed research into this period would be required. Hilpert, Die Menschenrechte, p. 141-145, describes how human rights enter partially the Catholic social teaching. 
Churches often adhered to hierarchical systems. ${ }^{95}$ However, we must not forget that at a practical level, the practice of human dignity (4) was an important field for the Churches or engaged Church representatives. ${ }^{96}$

\section{The Stimulating Effect of the Universal Declaration of Human Rights}

It is after World War II that the term dignity enters into the preamble and article 1 of the Universal Declaration of Human Rights of December 10, 1948.97 Menke and Pollmann suggest that the term human dignity came into play precisely because it was a neutral term and was not used predominantly by any of the diverse groups, such as Liberalism, Socialism, and Catholicism. ${ }^{98}$ As a consequence, both terms - human dignity and human rights - conquer not only the public domain, but also re-conquer theology. French Protestantism interpreted the introduction of human rights as a secular expression of the Protestant idea of human dignity and, at least initially, welcomed the concept. ${ }^{99}$ Also the Catholic Church, in spite of a long rejection, embraced rapidly the "consciousness of contemporary man" in the Second Vatican Council's Dignitatis humanae (7.12.1965). ${ }^{100}$ The Declaration argues that religious faith is founded in a free decision based on a personal search for truth, analogous

95 With regard to the German Protestant Churches, cf., e.g., Wippermann, Januskopf, p. 41-50.

96 Cf. Coleman/Baum, Rerum novarum. Leo XIII refers to human dignity when he argues for just remuneration and working conditions in his Encyclical Rerum Novarum. For the tradition of diacony, cf., e.g., Hope, German and Scandinavian Protestantism 1700-1908, p. 400-419.

97 UN General Assembly, Universal Declaration of Human Rights.

98 Menke/Pollmann, Philosophie der Menschenrechte, p. 131.

99 In a movement contrary to the Catholic Church, French Protestantism later moved to a distance from the human rights discourse because of the lack of religious foundation. The Catholic Church instead, had initially condemned the idea of human rights and freedom of religion because they did not respect the Catholic's Church claim to truth; however, the positions moved closer and finally, with Vatican II, integrated the idea of human rights into its own position. See Zuber, L'origine religieuse des droits de l'homme.

100 Dignitatis humanae, no. 1: "A sense of the dignity of the human person has been impressing itself more and more deeply on the consciousness of contemporary man, and the demand is increasingly made that men should act on their own judgment, enjoying and making use of a responsible freedom, not driven by coercion but motivated by a sense of duty. [...] To this end, it searches into the sacred tradition and doctrine of the Church-the treasury out of which the Church continually brings forth new things that are in harmony with the things that are old." For an overview, see Hollenbach, Human dignity in Catholic thought. 
to the freedom and judgment of conscience. This freedom that belongs intrinsically to the human person is therefore a precondition that the State must accept and which obliges the State to refrain from interfering in religious matters. ${ }^{101}$ By making this remarkable turn away from the previous century's understanding of moral conscience controlled by religious authority ${ }^{102}$, the Catholic Church thus takes a similar position that had already been proposed by Lactantius. It also interprets human dignity as a corner stone in the social teaching of the Church. ${ }^{103}$ Within theology, conscience and practical reason, free action, and responsible moral self-determination, which are intrinsically related to a modern understanding of human dignity ${ }^{104}$, were widely accepted and used as a basis for engaging in ethical discussions.

The idea that Christian Churches should strongly support human dignity and human rights yields many different tasks and challenges. Between the different Churches and confessions, it requires a broad inter-confessional effort, in which the aspects of human dignity that dominate the different Christian approaches to biblical interpretation and to tradition can be discussed and brought into a complementary relationship. ${ }^{105}$ In this way, a mutually

101 Siebenrock, Theologischer Kommentar zur Erklärung über die religiöse Freiheit Dignitatis humanae, p. 125-218.

102 On the changes in the Catholic Church's approach to conscience that took place during Vatican II cf. Golser, Gewissen und objektive Sittenordnung.

103 John Paul II, Apostolic Exhortation Ecclesia in America, in no. 55, refers to human dignity, solidarity and subsidiarity as threefold cornerstone of Catholic Social Teaching. I owe this reference to Anthony John Britto. For an overview on the topic, cf. Hittinger, Toward an Adequate Anthropology. For a view from Protestantism, cf. C. Ben Mitchell, The Audacity of the 'Imago Dei'.

104 Cf. Schockenhoff, Ethik des Lebens, p. 239.

105 An example for such a cooperation has been presented by a bilateral working group of the German Catholic bishops' conference and the United Evangelical-Lutheran Church of Germany which has published the text "God and the dignity of man". It summarizes the different accounts of human dignity in the Bible in four groups, namely (1) the dignity of the image of God (reasons from the theology of creation); (2) the dignity of true man (reasons from Christology); (3) the dignity of the person called to redemption (reasons from a theology of redemption); and (4) the dignity of the person called to perfection (eschatological reasons). The working group regards the dignity of the image of God as complementary to the other theological accounts. The text stresses that the neither the first nor the other accounts are mutually exclusive in the sense that an approach from creation would exclude the possibility of failure, or that an approach from redemption theology would depart from the idea that a fallen man is not anymore a human being. In 
reinforcing viewpoint can be used to create a strong narrative. However, from this short overview, some challenges emerge.

A first challenge concerns the idea of human rights as a legal consequence of one of the two main concepts that define human dignity in the Christian tradition. The historical overview illustrates that the equality of human beings is an ingredient of the Judeo-Christian anthropological tradition of the imago Dei paradigm, which was elaborated especially in the framework of natural law theory. The universal dimension of human dignity became a crucial issue sporadically, e.g., in times of religious persecution during the Roman Empire, but it took a long time to deduce legal consequences from it. Still today, some aspects of some human rights are not yet fully shared by some Christian churches, which shows that the process of translating human dignity into human rights requires time and direction, because it presupposes an evolving and renewed interpretation of one's own doctrine and faith tradition. The slow pace of interpretation in some Christian churches contradicts the driving force of the main messages of both concepts, universal equality of human beings and dignity of the human person.

The second challenge concerns the concept of human dignity, which is characterised by the reflection about who the human being exactly is and in tradition mainly refers to reflections about the human soul or the human person. Reason, self-reflection, self-determination, search for wisdom, transcendence, mystical union with God, language, sociability, moral responsibility, free will, and the capacity to shape the world, among other features, are characteristic of the human being and signs of excellence. It is obvious that founding human dignity in the moral capacity of the human being, which is one of the major philosophical approaches today, would be perceived as an important and fundamental dimension, but taken alone would present a certain limitation in light of the Christian tradition. One important additional dimension is the human capacity for transcendence, which is linked to an ultimate freedom of the person, of moral conscience, and of religion. There is something in human beings, created in the image and likeness of God, that is mysterious, just as God is mysterious, and therefore escapes exact description. Though some of the approaches related to this concept are particular because they relate directly to faith issues, the plurality of concepts developed in different stages of the

this way, the working group intends to overcome classical separation between a Catholic emphasis on reasons from the theology of creation and natural law, and a protestant highlighting theology of redemption. Cf. Bilaterale Arbeitsgruppe, Gott und die Würde des Menschen, p. 111-119, esp. p. 112 et seq. A combination of both lines requires that human freedom and divine grace are not regarded as mutually excluding conditions of human acting. Cf. Lerch, Freiheit des Menschen und Wirksamkeit der Gnade, p. 213-243. 
history of Christianity may serve as verification that reductionist approaches to human beings are not compatible with the Christian tradition.

A third challenge is evident in the relationship between the two Christian perspectives, the imago Dei paradigm and human dignity. It is important to know that when only the second perspective (individual and personal approaches to human dignity) was taken into consideration, the danger occurred that some persons were excluded from having dignity - because of a different faith, fewer rational capacities, or a dynamic interpretation of the capacities of the soul. Therefore, this perspective needs the universal and intrinsic perspective of the imago Dei paradigm as a corrective. A particular understanding of human dignity, be it religious or secular, logically presupposes a universal understanding of human dignity, since particular expressions rest on the fundamental and universal right to express religious faith and personal beliefs. Without acknowledging first, the universal dimension of equality, the particular dimension of human dignity has no foundation. In this regard, the imago Dei paradigm, which relates to universality, intrinsic worth, and which, already in its origin, explicitly does not regard particular faith questions, cannot be replaced, but only complemented by other theological dimensions of human dignity.

This insight relates to the four dimensions of human dignity, which served as a hermeneutical key for our historical overview. In the historical examples, frequently the general anthropological insight (1) and the request for legal consequences (3) go together, whereas the individual understanding (2) and the practical virtue approach (4) form partners more often. Yet the two groups are mutually dependent on one another. When laws are made and practical strategies developed to help human beings flourish $(3,4)$, then this presupposes that we recognize an intrinsic dignity of the human being (1) and that we know who a human person is so that we know what can make him or her flourish (2). Even if for the sake of reducing complexity the four aspects can be separated, they ought to be regarded as operating in an interconnected hermeneutical background to create mutual plausibility.

To keep a connection between the universal and more formal concept of "the" human being and his or her rights, on the one hand, and the more detailed understanding of human persons, their needs and possibilities of living a dignified and fulfilling life on the other hand, is a necessary task of modern pluralistic societies and the global world. In this sense, this overview suggests that Christian theologies can contribute to this task by offering descriptions and analyses of the human person, their dignity, and rights. Even more urgent, it seems, can be the contribution of constructing overarching narratives, which can support both the universal claim of the intrinsic human dignity of 
all human beings, and the particular interest in the flourishing of the individual human person, and by providing these narratives legal, cultural, social, and religious support in our contemporary world.

\section{Biography}

Sigrid Müller teaches Theological Ethics at the Catholic Theological Faculty of the University of Vienna since 2007. Her research interests cover the history of Moral Theology, Bioethics and Fundamental Questions of Moral Theology. She co-edits (with Stephan Goertz) the book series "Studien der Moraltheologie. New Series" [Studies in Moral Theology. New Series] and (with Piotr Morciniec) the practice-oriented book series Bioethics in discussion. Among her most recent publications are Philosophie und Theologie im Spätmittelalter [Philosophy and Theology in the Late Middle Ages], and Werte im Beruf [Ethical Values in professional activities] (co-edited with Stephanie Höllinger and Bettina Baldt). She is currently working on a Short History of Moral Theology (together with Kerstin Schlögl-Flierl).

\section{Bibliography}

Acts of the Christian Martyrs. Introduction, texts and translations by Herbert Musurillo.

Oxford: At the Clarendon Press, 1972.

Ambrosius: Exaemeron, in: Opera, Vol. 1,1 [1]. Ed. by Carolus Schenkl (CSEL 32/1 [1]). Prague/Vienna/Leipzig: F. Tempsky/G. Freytag, 1896.

Aquinas, Thomas: Summa theologiae: Secunda secundae, 92-189. Transl. by Laurence Shapcote; ed. by John Mortensen and Enrique Alarcón. Lander, WY: The Aquinas Institute for the Study of Sacred Doctrine, 2012.

Aquinas, Thomas: Summa theologiae: Secunda secundae, 1-91. Transl. by Laurence Shapcote; ed. by John Mortensen and Enrique Alarcón. Green Bay, WI: The Aquinas Institute, 2017.

Aquinas, Thomas: "Quaestiones disputatae de veritate a quaestione XXV ad quaestionem XXVI. Textum Taurini 1953 editum et automato translatum a Roberto Busa SJ in taenias magneticas denuo recognovit Enrique Alarcón atque instruxit", 2019, https://www.corpusthomisticum.org/qdv25.html\#57078 (date of last access: 19.03.2020).

Aquinas, Thomas: Summa Theologiae prima pars a quaestione XXVIII ad quaestionem XLIII. Textum Leoninum Romae 1888 editum et automato translatum a Roberto Busa SJ in taenias magneticas denuo recognovit Enrique Alarcón atque 
instruxit, 2019, https:/www.corpusthomisticum.org/sth1o28.html\#29676 (date of last access: 19.03.2020).

Assmann, Aleida: Menschenrechte und Menschenpflichten. Schlüsselbegriffe für eine humane Gesellschaft. Vienna: Picus Verlag, 2018.

Augustine: On the Trinity books 8-15. Ed. by Gareth B. Matthews, Transl. by Stephen McKenna. Cambridge: Cambridge University Press, 2002.

Barak, Aharon: Human Dignity. The Constitutional Value and the Constitutional Right. Translated from the Hebrew by Daniel Kayros. Cambridge: Cambridge University Press, 2015.

Barr, James: "The Image of God in the Book of Genesis - A Study of Terminology", in: Bulletin of the John Rylands Library $5^{1}$ (1968/69), p. 11-26.

Barth, Ulrich: "Gottebenbildlichkeit und Menschenwürde. Überlegungen zu einem kulturellen Transformationsprozess", in: Rudolf Langthaler/Hubert Philipp Weber (ed.): Evolutionsbiologie und Schöpfungsglaube. Neue Perspektiven in der Debatte. Göttingen: Vandenhoeck \& Ruprecht, 2013, p. 333-36o.

Bayer, Oswald: "Martin Luther's Concept of Human Dignity", in: Marcus Düwell/Jens Braarvig/Roger Brownsword/Dietmar Mieth (ed.): The Cambridge Handbook of Human Dignity. Interdisciplinary Perspectives. Cambridge: Cambridge University Press, 2014, p. 101-107.

Behr, John: "The Rational Animal: A Rereading of Gregory of Nyssa's De hominis opificio", in: Journal of Early Christian Studies 7 (2/1999), p. 219-247.

Bernard of Clairvaux: Concerning Grace and Free Will. Translated, with an introduction, synopsis and notes by Watkin W. Williams. New York, NY: The McMillan Company, 1920 [e-book: Aeterna Press, 2014].

Bilaterale Arbeitsgruppe der Deutschen Bischofskonferenz und der Vereinigten Evangelisch-Lutherischen Kirche Deutschlands: Gott und die Würde des Menschen. Paderborn/Leipzig: Bonifatius, 2017.

Böckenförde, Ernst-Wolfgang: Staat, Gesellschaft, Freiheit. Studien zur Staatstheorie und zum Verfassungsrecht. Frankfurt a.M.: Suhrkamp, 1976.

Boethius, Anicius Manlius Severinus: Contra Eutychen et Nestorium/Against Eutyches and Nestorius, in: The Theological Tractates; the Consolation of Philosophy. Ed. by H.F. Stewart, E.K. Rand and S.J. Tester. Cambridge, MA: Harvard University Press, 1973, p. 72-129.

Bonaventura: Itinerarium mentis in deum, in: Opera omnia, Vol. 5. Ed. PP. Collegiii a S. Bonaventura. Quaracchi: Collegium S. Bonaventurae, 1891, p. 293-316.

Bonaventura: Sermones selecti de rebus theologicis, in: Opera Omnia, Vol. 5. Ed. PP. Collegii a S. Bonaventura. Quaracchi: Collegium St. Bonaventurae, 1891, p. 533-579.

Breitsameter, Christof: "Sünde und Schuld zwischen Individuum und Kollektiv", in: Christof Breitsameter/Stephan Goertz (ed.): Bibel und Moral - Ethische und exegetische Zugänge, Freiburg i. Br.: Herder, 2018, p. 247-269. 
Cicero, Marcus Tullius: On Duties. Translated with introduction, notes, and indexes by Benjamin Patrick Newton. Ithaca, NY/London: Cornell University Press, 2016.

Coleman, John/Baum, Gregory (ed.): Rerum novarum. A hundred years of Catholic social teaching. London: SCM Press/Philadelphia, PA: Trinity Press International, 1991.

Cyprian: The Epistles, in: The Writings of Cyprian, Bishop of Carthage, Vol. 1, Epistles and Some of the Treatises. Transl. by Robert Ernest Wallis. Buffalo, NY. From Ante-Nicene Fathers, Vol. 5. Edited by Alexander Roberts, James Donaldson, and A. Cleveland Coxe. (Buffalo, NY: Christian Literature Publishing Co., 1886.), revised and edited for New Advent by Kevin Knight, 2017, http://www.newadvent.org/ fathers/0506.htm (date of last access: 14.03.2020).

Cyprian: The Treatises, in: The Writings of Cyprian, Bishop of Carthage, Vol. 1, Epistles and Some of the Treatises. Transl. by Robert Ernest Wallis. From Ante-Nicene Fathers, Vol. 5. Ed. by Alexander Roberts, James Donaldson, and A. Cleveland Coxe (Buffalo, NY: Christian Literature Publishing Co., 1886.), revised and edited for New Advent by Kevin Knight, 2017, http://www.newadvent.org/fathers/0507.htm (date of last access: 14.03 .2020 ).

Daniélou, Jean: Lêtre et le temps chez Grégoire de Nysse. Leiden: Brill, 1970.

Declaration on Religious Freedom Dignitatis Humanae on the Right of the Person and Communities to Social and Civil Freedom in Matters Religious, promulgated by Pope Paul VI, 07.12.1965, http://www.vatican.va/archive/hist_councils/ii_vatican_ council/documents/vat-ii_decl_19651207_dignitatis-humanae_en.html (date of last access: 04.03.2020).

Drewer, Mathew: "Image, Identity, and Embodiment: Augustine's Interpretation of the Human Person in Genesis 1-2", in: Nathan MacDonald/Mark W. Elliott/Grant Macaskill (ed.): Genesis and Christian Theology. Grand Rapids, MI/Cambridge: William B. Erdmans Publishing Company, 2012, p. 117-128.

Düwell, Marcus/Braarvig, Jens/Brownsword, Roger/Mieth, Dietmar (ed.): The Cambridge Handbook of Human Dignity. Interdisciplinary Perspectives. Cambridge: Cambridge University Press, 2014.

Ebneter, Thomas: Exsistere. Zur Persondefinition in der Trinitätslehre des Richard von St. Viktor (†1173). Fribourg: Academic Press, 2005.

Ellverson, Anna-Stina: The Dual Nature of Man. A Study in the Theological Anthropology of Gregory of Nazianzus. Uppsala: Uppsala Universitet, 1981.

Genesis 1-11. Übersetzt und ausgelegt von Georg Fischer. Freiburg/Basel/Wien: Herder, 2018.

Golser, Karl: Gewissen und objektive Sittenordnung. Zum Begriff des Gewissens in der neueren katholischen Moraltheologie. Vienna: Wiener Dom-Verlag, 1975.

Gregorius Magnus: Epistulae, in: Opera omnia, Vol. 3 (PL 77). Ed. Jacques-Paul Migne. Paris: Garnier et Migne, 1896, p. 440-1328. 
Gregory of Nyssa: The Life of Moses. Translation, introduction and notes by Abraham J. Malherbe and Everett Ferguson, Preface by John Meyendorff. New York, NY: Paulist Press, 1978.

Gregory of Nyssa: On the Making of Man, in: Dogmatic Treatises; Select Writings and Letters. Translated, with Prolegomena, Notes, and Indices by William Moore and Henry Austin Wilson. Edinburgh: T\&T Clark/Grand Rapids, MI: WM.B. Eerdemans Publishing Company, 1988 [reprint of Oxford: Parker \& Co, 1893]. Presented by The Common Man's Prospective by Ernest C. March, 1999-2012, http://ecmarsh.com/fathers/npnf2/NPNF2-05/Npnf2-05-36.htm\#P3055_2043494 (date of last access: 10.03.2020).

Gregory of Nyssa: De vita Moysis II, in: Gregorii Nysseni opera, Vol. 7.1. Ed. Herbertus Musurillo. Leiden: Brill, 1964.

Gregory the Great, The Letters, Vol. 2: Books 5-9. Translated, with introduction and notes by John R.C. Martyn. Toronto: Pontifical Institute of Mediaeval Studies, 2004, p. 324-712.

Große Kracht, Hermann-Josef: "Fünfzig Jahre Böckenförde-Theorem. Eine bundesrepublikanische Bekenntnisformel im Streit der Interpretationen”, in: Hermann-Josef Große Kracht/Klaus Große Kracht (ed.): Religion - Recht - Republik. Studien zu Wolfgang-Ernst Böckenförde. Paderborn: Schöningh, 2014, p. 155-183.

Hilpert, Konrad: Die Menschenrechte. Geschichte, Theologie, Aktualität. Düsseldorf: Patmos 1991.

Hittinger, F. Russel: “Toward an Adequate Anthropology. Social Aspects of Imago Dei in Catholic Theology", in: Thomas Albert Howard (ed.): Imago Dei. Human Dignity in Ecumenical Perspective. Washington, D.C.: Catholic University of America Press, 2013, p. 39-78.

Hollenbach, David: "Human Dignity in Catholic Thought", in: Marcus Düwell/Jens Braarvig/Roger Brownsword/Dietmar Mieth (ed.): The Cambridge Handbook of Human Dignity. Interdisciplinary Perspectives. Cambridge: Cambridge University Press, 2014, p. 250-259.

Hope, Nicholas: German and Scandinavian Protestantism 1700-1908. Oxford: Oxford University Press, 1995 .

Hugo de Sancto Victore: De Sacramentis Christianae fidei. Ed. Rainer Berndt. Münster: Aschendorff, 2008.

Imbach, Ruedi: "Human Dignity in the Middle Ages (twelfth to fourteenth century)", in: Marcus Düwell/Jens Braarvig/Roger Brownsword/Dietmar Mieth (ed.): The Cambridge Handbook of Human Dignity. Interdisciplinary Perspectives. Cambridge: Cambridge University Press, 2014, p. 64-73.

Janowski, Bernd: "Die lebendige Statue Gottes. Zur Anthropologie der priesterlichen Urgeschichte", in: Markus Witte (ed.): Gott und Mensch im Dialog. Festschrift für Otto Kaiser zum 80. Geburtstag. Berlin/Boston, MA: De Gruyter, 2004, p. 183-214. 
Jervell, Jacob: "Bild Gottes I", in: Theologische Realenzyklopädie, Vol. 6. Berlin/New York, NY: Walter de Gruyter, 1980, p. 491-498.

Joas, Hans: The Sacredness of the Person. A New Genealogy of Human Rights. Transl. by Alex Skinner. Washington, D.C.: Georgetown University Press, 2013.

John Paul II: Apostolic Exhortation Ecclesia in America, 22.1.1999, http://www. vatican.va/content/john-paul-ii/en/apost_exhortations/documents/hf_jp-ii_ exh_22011999_ecclesia-in-america.html (date of last access: 24.03.2020).

Kant, Immanuel: Groundwork of the Metaphyics of Morals. Translated and Ed. by Mary Gregor and Jens Timmermann, Translation Revised by Jens Timmermann with an Introduction by Christine M. Korsgaard. Cambridge: Cambridge University Press, 2012 [5th printing 2019].

Kant, Immanuel: The Metaphysics of Morals. Ed. by Lara Denis, Transl. by Mary Gregor. Cambridge: Cambridge University Press, 2017 [3rd printing 2019].

Kateb, George: Human Dignity. Cambridge, MA/London: The Belknap Press of Harvard University Press, 2011.

Kobusch, Theo: "Die Würde des Menschen - ein Erbe der christlichen Philosophie", in: Rolf Gröschner/Stephan Kirste/Oliver W. Lembcke (ed.): Des Menschen Würde entdeckt und erfunden im Humanismus der italienischen Renaissance. Tübingen: Mohr Siebeck, 2008, p. 235-250.

Lactantius, Venantius Honorius Clementianus Fortunatus: On the Workmanship of God, or the Formation of Man. Transl. by William Fletcher, in: Fathers of the Third and Fourth Centuries. Lactantius, Venantius, Asterius, Victorinus, Dionysius, Apostolic Teaching and Constitions, Homily, and Liturgies. American Edition chronologically arranged, with notes, prefaces, and elucidations by A. Cleveland Coxe. Buffalo, NY: Christian Literature Publishing Co., 1989 [Reprint of the edition Edinburgh: T\&T Clark, 1886], p. 280-30o.

Lactantius, Venantius Honorius Clementianus Fortunatus: The Divine Institutions. Transl. by William Fletcher, in: Fathers of the Third and Fourth Centuries. Lactantius, Venantius, Asterius, Victorinus, Dionysius, Apostolic Teaching and Constitions, Homily, and Liturgies. American Edition chronologically arranged, with notes, prefaces, and elucidations by A. Buffalo, NY: Christian Literature Publishing Co., 1989 [Reprint of the edition Edinburgh: T\&T Clark, 1886], p. 9-223.

Leo Magnus: Sermones, in: Opera omnia, Vol. 1. Ed. Petrus et Hieronymus Ballerini. accurante et denuo recognoscente Jacques-Paul Migne (PL 54). Paris: Garnier et Migne, 1881 , p. 117-467.

Leo the Great: Sermons. Transl. by Jane Patricia Freeland and Agnes Josephine Conway. Washington, D.C.: The Catholic University of America Press, 1995.

Leo XIII: Rerum Novarum, 15.05.1891, http://www.vatican.va/content/leo-xiii/en/ encyclicals/documents/hf_l-xiii_enc_15051891_rerum-novarum.html (date of last access: 02.05 .2020$)$. 
Lerch, Magnus: "Freiheit des Menschen und Wirksamkeit der Gnade - Verbindung von transzendentaler und existenzieller Perspektive in gnadentheologischer Absicht", in: Aaron Langenfeld/Magnus Lerch (ed.): Theologische Anthropologie. Paderborn: Ferdinand Schöningh, 2018, p. 213-243.

Manetti, Iannotius: De dignitate et excellentia hominis libriIV. Basel:Andreas Cratander, 1532, http://dx.doi.org/10.3931/e-rara-1740 (date of last access: 04.03.2020).

Marenbon, John: From the Circle of Alcuin to the School of Auxerre. Logic, Theology and Philosophy in the Early Middle Ages. Cambridge: Cambridge University Press, 1981.

McKeown, James: Genesis. Grand Rapids, MI/Cambridge:William B. Erdmans Publishing Company, 2008.

Meister Eckhart: Expositio sancti Evangelii secundum Iohannem, in: Die deutschen und lateinischen Werke: Die lateinischen Werke, Vol. 3. Ed. and transl. by Karl Christ. Stuttgart: Kohlhammer, 1994.

Menke, Christoph/Pollmann, Arnd: Philosophie der Menschenrechte zur Einführung. Hamburg: Junius, ${ }^{2} 2008$.

Mieth, Dietmar: "Human Dignity in Late-Medieval Spiritual and Political Conflicts", in: Marcus Düwell/Jens Braarvig/Roger Brownsword/Dietmar Mieth (ed.): The Cambridge Handbook of Human Dignity. Interdisciplinary Perspectives. Cambridge: Cambridge University Press, 2014, p. 74-84.

Mitchell C. Ben: "The Audacity of the Imago Dei. The Legacy and Uncertain Future of Human Dignity", in: Thomas Albert Howard (ed.): Imago Dei. Human Dignity in Ecumenical Perspective. Washington, D.C.: Catholic University of America Press, 2013, p. 79-112.

Müller, Sigrid: "Gemeinwohldenken im Mittelalter", in: Christian Hiebaum (ed.): Handbuch Gemeinwohl. Wiesbaden: Springer Fachmedien, 2020. https://doi.org/ 10.1007/978-3-658-21086-1 (in process of online-publication).

Nussbaum, Martha: The Cosmopolitan Tradition. A Noble but Flawed Ideal. Cambridge, MA/London: Harvard University Press, 2019.

Parliamentary Council: Basic Law for the Federal Republic of Germany in the Revised Version Published in the Federal Law Gazette Part II I, Classification Number 100-1, as Last Amended by Article 1 of the Act of 28 March 2019 (Federal Law Gazette I p. 404). Transl. by Christian Tomuschat, David P. Currie, Donald P. Kommers and Raymond Kerr, in Cooperation with the Language Service of the German Bundestag, 2019, https://www.gesetze-im-internet.de/englisch_gg/index.html (date of last access: 15.03 .2020$)$.

Pharo, Lars Kirkhusmo: "The Council of Valladolid (1550-1551). A European Disputation about the Human Dignity of Indigenous Peoples of the Americas", in: Marcus Düwell/Jens Braarvig/Roger Brownsword/Dietmar Mieth (ed.): The Cambridge Handbook of Human Dignity. Interdisciplinary Perspectives. Cambridge: Cambridge University Press, 2014, p. 95-100. 
Pico della Mirandola, Giovanni: On the Dignity of Man. Transl. by C. Wallis, Revised by P. Miller, in: On the Dignity of Man: On Being and the One: Heptaplus. Transl. by C. Wallis, P. Miller and D. Carmichael, Introd. by P. Miller. Indianapolis, IN: Hackett, 1998, p. 1-34.

Pinker, Steve: "The Stupidity of Dignity", in: Human Life Review 34 (2/2008), p. 75-82.

Pufendorf, Samuel von: De officio hominis et civis juxta legem naturalem libri duo, Vol. 1, Photographic Reproduction of the Edition of 1672 with an Introduction by Walther Schücking; Vol. 2, The Translation by Frank Gardner Moore. New York, NY [a.o.]: Oxford University Press, 1927.

Pufendorf, Samuel von: De jure naturae et gentium libri octo, Vol. 1: A Photographic Reproduction of the Edition of 1688 ; Vol. 2: The Translation by C.H. and W.A. Oldfather. New York, NY: Oxford University Press, 1934.

Rayner, A.J.: "Christian Society in the Roman Empire”, in: Greece \& Rome 11 (33/1942), p. $113^{-123 .}$

Richard de Saint-Victor: De trinitate. Ed. by J. Ribaillier. Paris: Vrin, $195^{8}$.

Saastamoinen, Kari: "Pufendorf on Natural Equality, Human Dignity, and Self-Esteem", in: Journal of the History of Ideas 71 (1/2010), p. 39-62.

Sacramentarium Veronense (Cod. Bibl. Capit. Veron. Lxxxv [8o]). Ed. by Leo Cunibert Mohlberg in Connection with Leo Eizenhöfer and Petrus Siffrin (RED.F I). Rome: Herder, corr. and amplified ed. ${ }^{3} 1978$.

Sandford, Stella: "Kant, Race, and Natural History", in: Philosophy and Social Criticism 44 (9/2018), p. 950-977.

Schaede, Stephan: "Würde - Eine ideengeschichtliche Annäherung aus theologischer Perspektive”, in: Petra Bahr/Hans Michael Heinig (ed.): Menschenwürde in der säkularen Verfassungsordnung. Rechtswissenschaftliche und theologische Perspektiven. Tübingen: Mohr Siebeck, 2006, p. 8-69.

Schelkshorn, Hans: Entgrenzungen. Ein europäischer Beitrag zum Diskurs der Moderne. Weilerswist: Velbrück Wissenschaft, 2009.

Schellenberg, Annette:Der Mensch, das Bild Gottes?Zum Gedanken einer Sonderstellung des Menschen im Alten Testament und in weiteren altorientalischen Quellen. Zürich: Theologischer Verlag, 2011.

Schockenhoff, Eberhard: Ethik des Lebens. Grundlagen und neue Herausforderungen. Freiburg/Basel/Wien: Herder, 2009.

Schüle, Andreas: Der Prolog der hebräischen Bibel. Der literar- und theologiegeschichtliche Diskurs der Urgeschichte (Genesis 1-11). Zürich: Theologischer Verlag Zürich, 2006.

Siebenrock, Roman: "Theologischer Kommentar zur Erklärung über die religiöse Freiheit Dignitatis humanae", in: Peter Hünermann/Bernd Jochen Hilberath (ed.): Herders Theologischer Kommentar zum Zweiten Vatikanischen Konzil. Freiburg/ Basel/Wien: Herder, 2009 [2005], p. 125-218. 
Steenbakkers, Piet: "Human Dignity in Renaissance Humanism”, in: Marcus Düwell/ Jens Braarvig/Roger Brownsword/Dietmar Mieth (ed.): The Cambridge Handbook of Human Dignity. Interdisciplinary Perspectives. Cambridge: Cambridge University Press 2014, p. 85-94.

Tesha, Michael Sia: Human Dignity as Basic Foundation for Morality in Perspective of 'Bantu' African Ethical Theory (With Specific Moral Challenges in Tanzania). Dissertation, University of Vienna, 2019.

UN General Assembly, Universal Declaration of Human Rights. 217 (III) A. Paris, 1948, http://www.un.org/en/universal-declaration-human-rights (date of last access: 19.03.2020).

Von der Pfordten, Dietmar: Menschenwürde. München: C.H. Beck, 2016.

Wagner, Hans: Die Würde des Menschen. Wesen und Normfunktion, in: Gesammelte Schriften, Vol. 2. Ed. by Bernward Grünewald. Paderborn/München/Wien/Zürich: Ferdinand Schöningh, 2014.

Wasmaier-Sailer, Margit: Das Verhältnis von Moral und Religion bei Johann Michael Sailer und Immanuel Kant. Zum Profil philosophischer Theologie und theologischer Ethik in der säkularen Welt. Regensburg: Verlag Friedrich Pustet, 2018.

Westerman, Pauline C.: "Natural Rights versus Human Dignity: Two Conflicting Traditions", in: Marcus Düwell/Jens Braarvig/Roger Brownsword/Dietmar Mieth (ed.): The Cambridge Handbook of Human Dignity. Interdisciplinary Perspectives. Cambridge: Cambridge University Press, 2014, p. 108-116.

Winger, Wolfram: Personalität durch Humanität. Das ethikgeschichtliche Profil christlicher Handlungslehre bei Lactanz, Parts 1-2. Frankfurt a.M./Berlin/Bern/New York, NY/Paris/Wien: Peter Lang, 1999.

Wippermann, Wolfgang: "Januskopf - Die Auswirkungen der Reformation auf das Verhältnis von Staat und Kirche", in: Ansgar Klein/Olaf Zimmermann (ed.): Impulse der Reformation. Der zivilgesellschaftliche Diskurs. Wiesbaden: Springer VS, 2017, p. 41-50.

Wolterstorff, Nicholas: "Toleration, Justice, and Dignity. Lecture on the Occasion of the Inauguration as Professor of Dirk-Martin Grube. Free University of Amsterdam, September 24, 2015", in: International Journal of Philosophy and Theology 76 (5/2015), p. 377-386, 03.06.2016, https://www.tandfonline.com/toc/rjpt2o/76/5 (date of last access: $25 \cdot 03.2020)$.

Zuber, Valentine: L'origine religieuse des droits de l'homme. Geneva: Labor et Fides, 2017. 